\title{
Greater osteoblast and endothelial cell adhesion on nanostructured polyethylene and titanium
}

This article was published in the following Dove Press journal:

International Journal of Nanomedicine

28 August 2010

Number of times this article has been viewed

\section{Theresa Raimondo \\ Sabrina Puckett \\ Thomas J Webster \\ School of Engineering and \\ Department of Orthopedics, Brown \\ University, Providence, RI, USA}

\begin{abstract}
Mostly due to desirable mechanical properties (such as high durability and low wear), certain synthetic polymers (such as polyethylene) and metals (such as titanium) have found numerous applications in the medical device arena from orthopedics to the vasculature, yet frequently, they do not proactively encourage desirable cell responses. In an effort to improve the efficacy of such traditional materials for various implant applications, this study used electron beam evaporation to create nanostructured surface features that mimic those of natural tissue on polyethylene and titanium. For other materials, it has been shown that the creation of nanorough surfaces increases surface energy leading to greater select protein (such as vitronectin and fibronectin) interactions to increase specific cell adhesion. Here, osteoblast (bone forming cells) and endothelial cell (cells that line the vasculature) adhesion was determined on nanostructured compared to conventional, nano-smooth polyethylene and titanium. Results demonstrated that nanorough surfaces created by electron beam evaporation increased the adhesion of both cells markedly better than conventional smooth surfaces. In summary, this study provided evidence that electron beam evaporation can modify implant surfaces (specifically, polyethylene and titanium) to have nanostructured surface features to improve osteoblast and endothelial cell adhesion. Since the adhesion of anchorage dependent cells (such as osteoblasts and endothelial cells) is a prerequisite for their long-term functions, this study suggests that electron beam evaporation should be further studied for improving materials for various biomedical applications.
\end{abstract}

Keywords: nanotechnology, polyethylene, osteoblasts, orthopedics, vascular, titanium

\section{Introduction}

Since their advent at the end of the nineteenth century, synthetic polymers have been increasingly used in health care. Applications include: controlled drug delivery systems, artificial hearts, total hip replacements, and dentistry. ${ }^{1}$ However, polymers (in particular, polyethylene) often demonstrate poor cytocompatibility properties requiring calcium phosphate or hydroxyapatite coatings to promote bone formation for orthopedic applications. ${ }^{2}$ Similarly, although improved, titanium also has less than desirable cytocompatibility properties sometimes requiring hydroxyapatite or other calcium phosphate coatings to increase bone growth for select orthopedic applications.

While the chemistry of polyethylene and titanium has been altered through various chemical functionalization strategies, few attempts have focused on changing surface roughness of these materials at the nanoscale to promote select cell function. ${ }^{2}$ In this light, nanotechnology (or the use of materials with at least one dimension less than $100 \mathrm{~nm}$ ) is attractive to improve the function of today's medical device materials
Correspondence: Thomas JWebster

School of Engineering and

Department of Orthopedics, Brown

University, Providence, RI, 02917 USA

$\mathrm{Tel}+\mid$ 40| 8632318

Fax + I 4018639107

Email thomas_webster@brown.edu 
since nanosurface features can easily modify implant surface energy to control initial protein adsorption. ${ }^{2-10}$ Since proteins adsorb to an implanted material before cells adhere, they control cell adhesion. Studies have shown that surface energy and surface nano-topography influence the type and concentration of adsorbed proteins. ${ }^{2,3}$

Various engineering methods have been used to generate nanostructured surfaces on medical devices, including but not limited to: anodization, powder metallurgy, chemical etching, lithography, cast-mold techniques, etc. ${ }^{2-10}$ For those tested in the orthopedic and vascular stent community, greater in vivo bone growth and in vitro endothelial cell responses have been observed. ${ }^{2-10}$ Recent studies have also highlighted decreased inflammatory cell (such a macrophage and platelet) functions on nanostructured compared to conventional materials. ${ }^{2-10}$ Moreover, recent studies have also highlighted decreased bacteria (such as Staph. epidermidis) functions on materials with nanostructured surface features created by electron beam evaporation compared to convention, nano-smooth metals and polymers. ${ }^{2-10}$ Collectively, such studies highlight the importance nanotechnology can play towards modifying implant surface properties to control cell responses important for increasing tissue growth, decreasing chronic inflammation, and decreasing implant infection. ${ }^{2-10}$

For all of the above reasons, this study fabricated nanorough titanium $(\mathrm{Ti})$ and polyethylene $(\mathrm{PE})$ surfaces through the use of electron beam evaporation (a new nanofabrication process to the medical device community). In addition, this study examined the effects of such nanofeatures on osteoblast (bone forming cells) and endothelial cell (cells that line the vasculature) adhesion.

\section{Materials and methods Electron beam evaporation}

A Temescal Electron Beam Evaporator (Reston, VA, USA) was used to create nanofeatures on $\mathrm{Ti}$ and polyethylene substrates (Figure 1). Electron beam evaporation concentrates a large amount of heat produced by high energy electron beam bombardment on the source material to be deposited, in this case $99.995 \%$ pure Ti pellets (Kamis, Mahopac Falls, NY, USA) on both Ti and polyethylene (Fisher Scientific, Minneapolis, MN, USA). The electron beam is generated by an electron gun that uses the thermoionic emission of electrons produced by an incandescent filament. A magnet focuses and bends the electron trajectory so that the beam is accelerated towards a graphite crucible (Lesker, Clairton, PA, USA) containing the source material. As the beam rotates and hits the surface of the source material, heating and

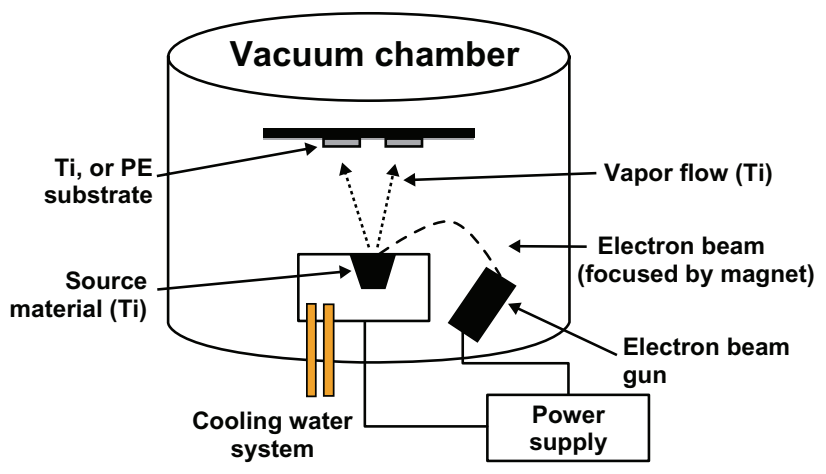

Figure I Schematic diagram of the electron beam evaporation process used in this study to create nanometer surface features on $\mathrm{PE}$ and $\mathrm{Ti}$.

vaporization occur. The vapor flow then condenses onto the substrate surface located at the top of the vacuum chamber. One can increase coating density by increasing the time of electron beam evaporation, possibly creating thicker coatings and thus, altering surface roughness.

In this study, Ti was deposited by electron beam evaporation onto the $\mathrm{Ti}$ and polyethylene $(\mathrm{PE})$ substrates at a rate of $3.5 \AA / \mathrm{s}$ and at a thickness of $500 \mathrm{~nm}$. Following deposition, the conventional (unmodified) and nanorough Ti samples were rinsed thoroughly with DI, air dried, and sterilized in a steam autoclave at $120^{\circ} \mathrm{C}$ and $17 \mathrm{psi}$ for $30 \mathrm{~min}$. The conventional (unmodified) and nanorough polyethylene samples were sterilized by UV light exposure for 24 hours.

\section{Material characterization SEM}

For qualitative surface roughness analysis, scanning electron microscopy (SEM) was performed on the conventional and nanorough $\mathrm{Ti}$ and $\mathrm{PE}$ substrates. Images were taken using a LEO 1530VP SEM at various magnifications. Digital images were created using secondary electrons collected with an in-lens detector at an accelerating voltage of $3 \mathrm{kV}$ for the conventional and nanorough $\mathrm{Ti}$ and PE substrates.

\section{Contact angles}

Material surface energy and wettability were investigated with a drop shape analysis system (EasyDrop, Kruss, Hamburg, Germany). The contact angle from $3 \mu \mathrm{L}$ sessile droplets was measured at three locations on each of the four samples (the nanorough and conventional $\mathrm{Ti}$ as well as nanorough and conventional PE). To determine surface energy, three different liquid solvents (specifically, distilled water, glycerol, and polyethylene glycol) were used. Measurements were taken $5 \mathrm{sec}$ after placing the droplet on the sample surface under 
ambient conditions. Drop shape analysis software (DSA1, Kruss, Hamburg, Germany) was used to calculate surface energy by entering surface tension and contact angle data into the Owens-Wendt equation. ${ }^{11}$

$$
1+\gamma_{1} \cos \theta=2\left(\sqrt{\left(\gamma_{s}^{d} \gamma_{l}^{d}\right)}+\sqrt{\left(\gamma_{s}^{p} \gamma_{l}^{p}\right)}\right)
$$

Here, $\gamma_{s}^{d}$ and $\gamma_{s}^{p}$ are the respective dispersion and polar terms of the solid surface tension, $\gamma_{\mathrm{s}} ; \gamma_{l}^{d}$ and $\gamma_{l}^{p}$ are the respective dispersion and polar terms of the liquid surface tension, $\gamma_{l}$. Other theories were investigated (Fowkes and Zisman) but results showed the same trends of surface energy as those obtained with the Owens-Wendt model.

\section{Cells}

\section{Osteoblasts}

Commercially available human osteoblasts (bone-forming cells, CRL-11372, American Type Culture Collection; passage numbers less than 3) were cultured in Dulbecco's Modified Eagles Medium (DMEM, Hyclone; Logan, UT, USA) supplemented with 10\% fetal bovine serum (FBS, Hyclone) and $1 \%$ penicillin-streptomycin ( $\mathrm{P} / \mathrm{S}$, Hyclone) under standard cell culture conditions $\left(5 \% \mathrm{CO}_{2} / 95 \%\right.$ humidified air environment at $37^{\circ} \mathrm{C}$ ).

\section{Endothelial cells}

Rat aortic endothelial cells (RAEC; population numbers less than 9) were purchased from VEC Technologies, cultured in MCDB-131 Complete Medium with serum (VEC Technologies; Rensselaer, NY, USA) under standard cell culture conditions $\left(5 \% \mathrm{CO}_{2} / 95 \%\right.$ humidified air environment at $37^{\circ} \mathrm{C}$ ).

\section{Cell experiments}

Before experiments, all substrates were immersed in $5 \mathrm{~mL}$ of either cell culture media in 6-well culture plates. Osteoblasts and RAEC were lifted from cell culture plates using trypsin/ ethylenediaminetetraacetic acid (EDTA) and were counted for seeding densities using a hemacytometer. For cell adhesion experiments, osteoblasts and RAEC were seeded at a density of 4500 cells $/ \mathrm{cm}^{2}$ onto the substrates of interest to this study. Cells were allowed to adhere onto the substrates for 4 hours under standard cell culture conditions. After the prescribed time period, non-adherent cells were removed by rinsing and adherent cells were fixed with formaldehyde, stained with Hoescht, and counted using a fluorescent microscope (Leica).

\section{Statistical analyses}

Data were collected by counting cells using fluorescence microscopy at five random fields per substrate. All experiments were completed in triplicate and repeated at least three different times. Statistical analysis of the data was performed by using Student $t$-tests to determine differences between means $(P<0.01$ was considered significant $)$.

\section{Results Surface characterization}

As expected, the conventional unmodified titanium (Ti) as purchased from the vendor possessed micron rough surface features (Figure 2). In contrast, after electron beam evaporation, the Ti substrates possessed a high degree of nanometer surface features. Similarly, conventional unmodified PE as purchased from the vendor were nano-smooth, as compared to the electron beam evaporated PE which was nanorough.

\section{Surface energy and contact angles}

Surface energy calculations from contact angle measurements data indicated that the resulting increased nanometer surface roughness increased surface energy for PE and Ti (Figure 3). The nanorough Ti and PE surfaces had surface energies significantly higher than respective unmodified substrates. The nanorough surfaces had lower contact angles for the DI water and polyethylene glycol (PEG), indicating greater surface energy on such samples compared to respective unmodified surfaces (Table 1).

\section{Osteoblast adhesion}

Most importantly, results of the present study revealed that after 4 hours, osteoblast adhesion increased on the nanorough Ti and PE substrate modified through electron beam evaporation, as compared to respective conventional unmodified substrates (Figure 4). As expected, osteoblast adhesion was significantly greater $(P<0.01)$ on the conventional unmodified Ti substrate as compared to the conventional unmodified PE substrate. Interestingly, however, osteoblast adhesion was significantly greater $(P<0.05)$ on the nanorough $P E$ surface as compared to the nanorough Ti surface after 4 hours.

\section{Endothelial adhesion}

Results of the present study revealed that after 4 hours, endothelial cell adhesion increased on the nanorough $\mathrm{Ti}$ and PE substrates created by electron beam evaporation compared to respective conventional unmodified substrates (Figure 5). Also as expected, endothelial cell adhesion was significantly greater $(P<0.01)$ on the conventional 

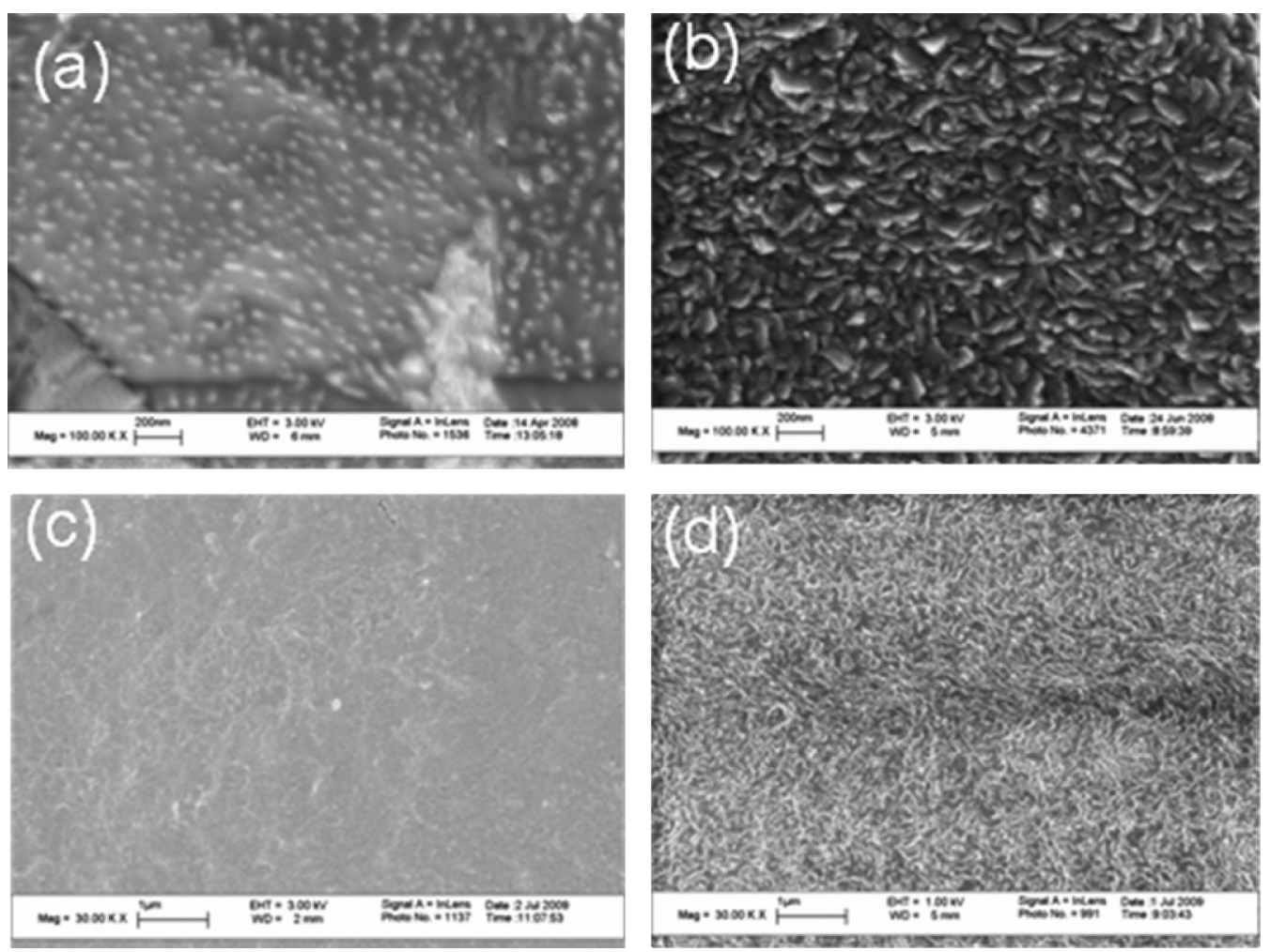

Figure 2 Scanning electron microscopy images of (a) conventional Ti, (b) nanorough Ti, (c) conventional PE, and (d) nanorough PE. Scale bars in (a) and (b) are $200 \mathrm{~nm}$ while in (c) and (d) are I $\mu \mathrm{m}$.

unmodified Ti substrates as compared to the conventional unmodified PE substrates. However, the nanorough Ti and PE substrates had similar numbers of endothelial cells after 4 hours.

\section{Discussion}

Synthetic polymers, such as polyethylene, and metals, such as titanium, have been used for many decades in the medical device industry. These materials have been used as bone and joint prosthetics, prosthetic heart valves, arterial stents,

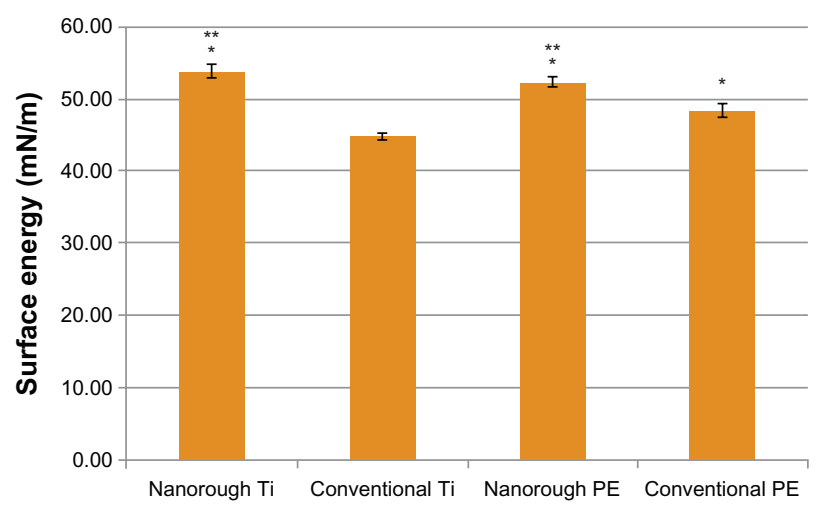

Figure 3 Greater surface energy for the nanorough Ti and nanorough PE compared to conventional Ti and conventional PE, respectively. Data are mean $\pm S E M ; n=4$. $* P<0.0$ I compared to conventional $\mathrm{Ti} ; * * P<0.01$ compared to conventional PE. and controlled drug delivery systems. Traditionally, these systems consist of materials which have surface roughness at the micron scale, on the order of 1 to $10^{4} \mu \mathrm{m} .{ }^{2}$ However all biological systems, including bone and vascular tissue, are nanostructured since they are composed of proteins (such as various types of collagen); the nanoscale roughness of bone and the vasculature are similar. ${ }^{2}$ Nanostructured materials are attractive compared to micron-structured materials for medical applications as their surfaces more closely approximate natural tissue surfaces in the body and their surface energy can be easily controlled by the size and amount of nanometer surface features.

While it is true that surfaces with nanoscale features have increased surface area compared to those without nanoscale surface features, this increased surface area has not increased

Table I Nanorough Ti and nanorough PE are less hydrophobic than their conventional counterparts

\begin{tabular}{llll}
\hline Surface type & $\begin{array}{l}\text { Contact angle } \\
\text { of DI water }\end{array}$ & $\begin{array}{l}\text { Contact angle } \\
\text { of glycerol }\end{array}$ & $\begin{array}{l}\text { Contact angle } \\
\text { of PEG }\end{array}$ \\
\hline Nanorough $\mathrm{Ti}$ & $59.3 \pm 1.13$ & $57.6 \pm 0.89$ & $28.3 \pm 1.74$ \\
Conventional $\mathrm{Ti}$ & $70.6 \pm 1.58$ & $69.3 \pm 0.84$ & $41.18 \pm 1.20$ \\
Nanorough $\mathrm{PE}$ & $55.08 \pm 1.64$ & $69.90 \pm 1.52$ & $18.80 \pm 1.71$ \\
Conventional PE & $95.60 \pm 0.32$ & $69.79 \pm 1.18$ & $41.40 \pm 0.78$ \\
\hline
\end{tabular}




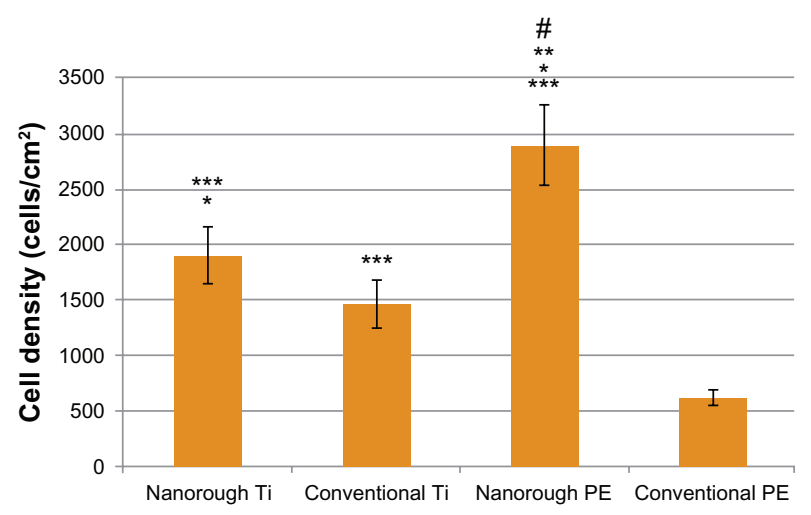

Figure 4 Greater osteoblast adhesion on nanorough $\mathrm{Ti}$ and nanorough $\mathrm{PE}$ as compared to their conventional counterparts. Data are mean $\pm S E M ; n=3$. $* \mathrm{P}<0.05$ compared to conventional $\mathrm{Ti} ; * \mathrm{*} P<0.0$ l compared to nanorough $\mathrm{Ti}$; *** $P<0.0$ l compared to conventional PE; ${ }^{*} P<0.0$ l compared to conventional $\mathrm{Ti}$. Culture time $=4$ hrs.

the adhesion of other cells (such as fibroblasts or bacteria), thus the altered surface energy possessed by nanomaterials has been implicated as their novel feature promoting tissue growth. ${ }^{2}$ This is because it has been shown that nanoscale materials can adsorb select proteins over microscale materials. Adsorption of select proteins can subsequently guide the adhesion and other function of cells on the medical device surface. ${ }^{12,13,16}$ As this study also accomplished, contact angles measured from various liquids on the surface of materials is a well established methodology to determine surface energy. ${ }^{13,14}$ Lower contact angles indicate higher surface energy. A number of studies have demonstrated improved cell adhesion and proliferation on nanorough surfaces of benefit for various tissues including the bladder, bone, vasculature, and nervous systems. ${ }^{1-10,15,16}$

The current study explored a new way to create nanorough surfaces by depositing Ti onto the surface of PE and Ti substrates, materials commonly used in orthopedic and

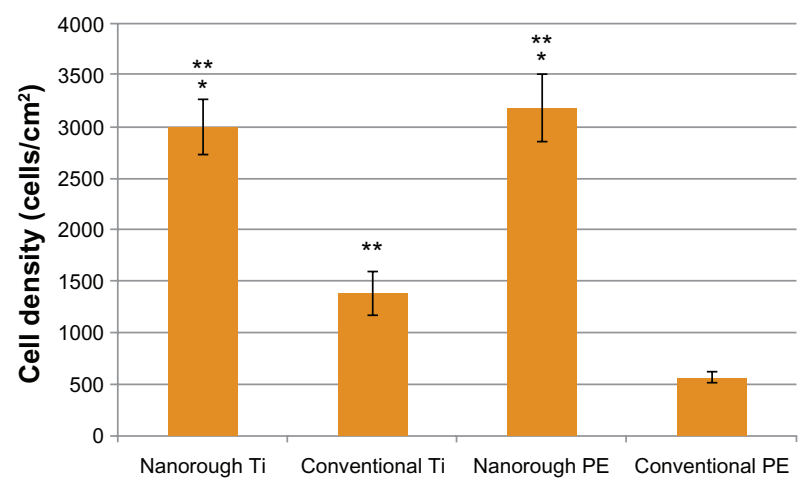

Figure 5 Greater endothelial cell adhesion on nanorough $\mathrm{Ti}$ and nanorough PE as compared to their conventional counterparts. Data are mean $\pm \mathrm{SEM} ; \mathrm{n}=3$. $* P<0.0$ l compared to conventional Ti; $* * P<0.01$ compared to conventional PE. Culture time $=4 \mathrm{hrs}$. vascular applications. In this technique, heat is concentrated onto the materials to be deposited (here, Ti) by electron bombardment. Vaporization of the materials then occurs with subsequent deposition on the PE or Ti substrate creating a nanorough surface on both substrates. In this manner, electron beam evaporation could be an easy process to employ at the end of almost any medical device manufacturing processing.

Here, it was shown that the surface energy of the PE and Ti substrates increased after creation of nanorough surface features as opposed to the respective conventional surface. Surface energy was determined by measuring contact angles of DI water, PEG, and glycerol. The surface energy of the PE with nanorough titanium surface was $52.43 \pm 0.62 \mathrm{mN} / \mathrm{m}$ as opposed to the surface energy of the conventional PE surface which was $48.45 \pm 0.88 \mathrm{mN} / \mathrm{m}(P<0.01)$. Similar results were found for the Ti substrate. Specifically, the surface energy of the nanorough Ti surface was $53.93 \pm 0.91 \mathrm{mN} / \mathrm{m}$ as opposed to the conventional Ti surface, $44.81 \pm 0.43 \mathrm{mN} / \mathrm{m}$ $(P<0.01)$. These are significant increases in surface energy to influence biological functions achieved through the electron beam evaporation process.

Since the surface energy of the nanorough surfaces increased on both substrates, one would anticipate altered cell responses. This study demonstrated that four hours after osteoblast seeding on the PE surface, cell adhesion greatly increased as opposed to the conventional PE surface. The osteoblast density on the nanorough PE substrate was $2893.5 \pm 366$ cells $/ \mathrm{cm}^{2}$ compared to $619.4 \pm 69$ cells $/ \mathrm{cm}^{2}$ on the conventional PE surface. Similarly, osteoblast adhesion was greater on the Ti with the nanorough surface with $1903.4 \pm 255$ cells $/ \mathrm{cm}^{2}$ as opposed to the conventional titanium surface that had an osteoblast density of $1464.1 \pm 214$ cells $/ \mathrm{cm}^{2}(P<0.05)$. Interestingly, the improvement in osteoblast adhesion due to the presence of nanorough surface features was much greater on PE than Ti. Such results suggest that it may not be necessary to coat PE with hydroxyapatite to improve bone cell responses (which may suffer from delamination problems), rather the process used here may increase osteoblast functions on nanorough $\mathrm{PE}$.

Similar to osteoblast cell adhesion, endothelial cell adhesion increased significantly when creating titanium nanorough surface features on Ti or PE. Specifically, within four hours of seeding endothelial cells onto the PE substrate, cell adhesion was much greater on the PE with the nanorough surfaces with a cell density of $3180.9 \pm 328$ cells $/ \mathrm{cm}^{2}$, as opposed to a cell density of $558.0 \pm 55$ cells $/ \mathrm{cm}^{2}$ on the conventional PE surface $(P<0.01)$; this was over a 6 time improvement. 
Similarly, cell adhesion was much greater on the Ti substrates with the nanorough surface features, with a cell density of $3006.3 \pm 265$ cells $/ \mathrm{cm}^{2}$, as opposed to a cell density of $1384.2 \pm 205$ cells $/ \mathrm{cm}^{2}$ on the conventional Ti surface. Since $\mathrm{Ti}$ is one of the most widely used medical device materials in vascular stent applications, often requiring a polymer coating to promote endothelialization, such results suggest that nanorough Ti alone may promote endothelialization.

\section{Conclusion}

In summary, the present in vitro study provided evidence that electron beam evaporation of titanium is a useful method to generate nanorough surfaces on both titanium and polyethylene substrates to increase surface energy and promote surface osteoblast and endothelial cell adhesion. Since adhesion of anchorage dependent cells is important for their subsequent functions (such as extracellular matrix synthesis), the present results imply improved osteoblast and endothelial cell long-term functions. Finally, electron beam evaporation of titanium appeared to be more effective on polyethylene surfaces than titanium surfaces in terms of generating nanoroughness. Thus, this study provided evidence that electron beam evaporation should be further studied for improving orthopedic and vascular applications.

\section{Acknowledgment}

The authors would like to thank Brown University for an Undergraduate Teaching and Research Award for the financial support for this study.

\section{Disclosure}

No conflicts of interest were declared in relation to this paper.

\section{References}

1. Langer R, Tirrel D. Designing materials for biology and medicine. Nature. 2004;428-433.

2. Balasundaram G, Webster TJ. An overview of nano-polymers for orthopedic applications. Macromol Biosci. 2007;7:635-642.

3. Webster TJ. Nanotechnology for the regeneration of hard and soft tissues. 2007. Singapore: World Scientific Publishers.

4. Puckett S, Taylor E, Raimondo T, Webster TJ. The relationship between the nanostructure of titanium surfaces and bacterial attachment. Biomaterials. 2010;31(4):706-713.

5. Taylor E, Webster TJ. The use of superparamagnetic nanoparticles for biofilm prevention. Int J Nanomed. 2009;4:145-152.

6. Gillani R, Ercan B, Qiao A, Webster TJ. Nanofunctionalized zirconia and barium sulfate particles as bone cement additives. Int J Nanomed. 2010;5:1-11.

7. Samaroo H, Lu J, Webster TJ. Enhanced endothelial cell density on NiTi surfaces with sub-micron to nanometer roughness. Int J Nanomed. 2008;3(1):1-10.

8. Tran N, Webster TJ. Nanotechnology for bone materials. Wiley Interdiscip Rev Nanomed Nanobiotechnol (WIREs). 2009;1(3):336-351.

9. Puckett S, Lee PP, Ciombor DM, Aaron RK, Webster TJ. Nanometer surface textured titanium surfaces for enhancing skin growth. Acta Biomaterialia. 2010;6/6:2352-2362.

10. Yang L, Webster TJ. Nanotechnology controlled drug delivery for treating bone diseases. Expert Opin Drug Deliv. 2009;6(8):851-864.

11. Donlan RM. Biofilms and device-associated infections. Emerg Infect Dis. 2001;7:277-281.

12. Schakenraad JM. Biomaterial science. Ratner BD, Hoffman AS, Schoen FJ, Lemons JE (eds). 1st edition. 1996. San Diego: Academic Press, Inc. p 140.

13. Liu H, Slamovich SB, Webster TJ. Increased osteoblast functions among nanophase titania/poly(lactide-co-glycolide) composites of the highest nanometer surface roughness. J Biomed Mater Res. 2006;78: 798-805.

14. Webster TJ, Ergun C, Doremus RH, Siegel RW, Bizios R. Specific proteins mediate enhanced osteoblast adhesion on nanophase ceramics. J Biomed Mater Res. 2000;51:475.

15. Thapa A, Miller DC, Webster TJ, Haberstroh K. Nano-structured polymers enhance bladder smooth muscle cell function. Biomaterials. 2003;24:2915.

16. Price RL, Ellison K, Haberstroh KM, Webster TJ. Nanometer surface roughness increases select osteoblast adhesion on carbon nanofibers. J Biomed Mater Res. 2004;70:129.
International Journal of Nanomedicine

\section{Publish your work in this journal}

The International Journal of Nanomedicine is an international, peerreviewed journal focusing on the application of nanotechnology in diagnostics, therapeutics, and drug delivery systems throughout the biomedical field. This journal is indexed on PubMed Central, MedLine, CAS, SciSearch $\AA$, Current Contents ${ }^{\circledR} /$ Clinical Medicine,

\section{Dovepress}

Journal Citation Reports/Science Edition, EMBase, Scopus and the Elsevier Bibliographic databases. The manuscript management system is completely online and includes a very quick and fair peer-review system, which is all easy to use. Visit http://www.dovepress.com/ testimonials.php to read real quotes from published authors. 